\title{
Plant- and Seaweed-Based Extracts Increase Yield but Differentially Modulate Nutritional Quality of Greenhouse Spinach through Biostimulant Action
}

\author{
Youssef Rouphael ${ }^{1}$, Maria Giordano ${ }^{1}$, Mariateresa Cardarelli ${ }^{2}$, Eugenio Cozzolino ${ }^{3}$, \\ Mauro Mori ${ }^{1}$, Marios C. Kyriacou ${ }^{4}$, Paolo Bonini ${ }^{5}$ (iD) and Giuseppe Colla ${ }^{6, *}$ (iD \\ 1 Department of Agricultural Sciences, University of Naples Federico II, 80055 Portici, Italy; \\ youssef.rouphael@unina.it (Y.R.); maria.giordano@unina.it (M.G.); mauro.mori@unina.it (M.M.) \\ 2 Consiglio per la ricerca in agricoltura e l'analisi dell'economia agraria, Centro di Ricerca Orticoltura e \\ Florovivaismo, 84098 Pontecagnano, Italy; mteresa.cardarelli@crea.gov.it \\ 3 Council for Agricultural Research and Agricultural Economy Analysis - Research Centre for Cereal and \\ Industrial Crops, 81100 Caserta, Italy; eugenio.cozzolino@crea.gov.it \\ 4 Department of Vegetable Crops, Agricultural Research Institute, 1516 Nicosia, Cyprus; \\ m.kyriacou@ari.gov.cy \\ 5 NGAlab, 43762, La Riera de Gaia, Tarragona, Spain; pb@ngalab.com \\ 6 Department of Agricultural and Forestry Sciences, University of Tuscia, 01100 Viterbo, Italy \\ * Correspondence: giucolla@unitus.it; Tel.: +39-0761-357536
}

Received: 30 June 2018; Accepted: 19 July 2018; Published: 21 July 2018

\begin{abstract}
Plant biostimulants (PBs) such as protein hydrolysates and seaweed extracts are attracting the increasing interest of scientists and vegetable growers for their potential toenhance yield and nutritional quality. The current study assessed crop productivity, leaf colorimetry, mineral profile and bioactive compounds of greenhouse spinach in response to the foliar application of three PBs: legume-derived protein hydrolysate $[\mathrm{PH}]$, extract of seaweed Ecklonia maxima or mixture of vegetal oils, herbal and seaweed Ascophyllum nodosum extracts. Plants were PB-treated at a rate of $3 \mathrm{~mL} \mathrm{~L}^{-1}$ four times during their growth cycle at weekly intervals. Foliar PB applications enhanced fresh yield, dry biomass and leaf area of spinach in comparison with untreated plants. Improved yield performance with PB applications was associated with improved chlorophyll biosynthesis (higher SPAD index). The three PB treatments elicited an increase in bioactive compounds (total phenols and ascorbic acid), thus raised the functional quality of spinach. The application of $\mathrm{PH}$ enhanced $\mathrm{K}$ and $\mathrm{Mg}$ concentrations and did not result in increased nitrate accumulation as observed with the other two PB treatments. Our findings can assist vegetable farmers and the agro-food industry in adopting innovative and sustainable tools such as PB for complementing a high yield with premium quality.
\end{abstract}

Keywords: ascorbic acid; mineral profile; natural biostimulants; nitrate; nutritional quality; Spinacia oleracea L.; sustainable horticulture

\section{Introduction}

The pressing issue of global food security coupled with the projections for global population increase and climate change pose major challenges for the horticultural industry and researchers with respect to sustainability, dictating maximization of the production per unit area while minimizing the environmental impact of vegetable cropping systems [1]. One of the most promising tools to tackle these rising concerns appears to be the use of plant biostimulants (PBs) which include natural substances (humic acids, protein hydrolysates and seaweed extracts) and beneficial microorganisms (mycorrhizal fungi and plant growth promoting rhizobacteria of strains belonging to the genera 
Azospirillum, Azotobacter and Rhizobium spp.) [2-6]. As defined by the European Biostimulant Industry Council (EBIC), PBs are 'substances and/or microorganisms applied to plants with the intention to enhance nutrition efficiency, abiotic stress tolerance and/or crop quality traits, regardless of its nutrients content' [7]. According to Colla et al. [8,9] and Battacharyya et al. [10], protein hydrolysates (PHs) along with macro-algae seaweed extracts (SWE) represent two important categories of natural substances PBs. The main components of commercial PHs are a mixture of free amino acids, oligo- and polypeptides sourced from animal or plant origins [11]; whereas commercial SWE, in particular the brown macro-algae (Ascophyllum nodosum and Ecklonia maxima), are important sources of polysaccharides (alginates, fucoidans, laminarans and mannitol), phenolic compounds as well as phytohormones (auxins, cytokinins, gibberellins, and brassinosteroids) [10,12,13].

Several studies conducted on a wide range of horticultural crops reported that foliar or substrate drench application of PHs, SWE as well as plant extracts (PEs) can stimulate the primary and secondary metabolism in plants by improving nutrient uptake and assimilation, by promoting the synthesis and accumulation of phytochemicals as well as enhancing the tolerance to abiotic stressors thus boosting crop yields [14-23]. The increase in crop productivity induced by PHs, SWEs and PEs application under both optimal and sub-optimal conditions could be associated with several direct and indirect interactive mechanisms, including: (i) stimulation of enzymatic activities involved in C and $\mathrm{N}$ metabolism, the Krebs cycle and glycolysis; (ii) elicitation of hormone-like activity, particularly that attributed to auxin and gibberellins; and (iii) enhancement of the nutritional status of treated plants through the modulation of root system architecture (length, density and number of lateral roots) $[2,8-10]$.

In addition to the pressing issue of maximizing the production of vegetable crops, the demand for high quality horticultural products is also on the rise, driven by the growing interest of society in fresh products of high nutritional and functional quality. The quality of fresh horticultural crops has been recently defined as 'a dynamic composite of their physicochemical properties and evolving consumer perception, which embraces organoleptic, nutritional and bioactive components' [24]. A paucity of information nonetheless exists in scientific literature concerning the biostimulant-mediated effects on the organoleptic, nutritional and bioactive components of quality in fresh horticultural products $[25,26]$. For instance, Ertani et al. [26] reported that foliar application of a PH derived from alfalfa plants at $50 \mathrm{~mL} \mathrm{~L}^{-1}$ increased the concentration of chlorogenic acid and the antioxidant capacity of green pepper fruits. Similarly, Fan et al. [25] revealed that root application of a commercial extract of brown seaweed (Ascophyllum nodosum) at $1.0 \mathrm{~g} \mathrm{~L}^{-1}$ stimulated flavonoid synthesis and induced significant increase in total phenolic concentration and antioxidant activity in spinach. Spinach (Spinacia oleracea L.) is an important leafy vegetable crop widely cultivated in the Mediterranean area under both open-field and greenhouse conditions. Italy is the European leader in the production of leafy vegetables destined as fresh-cut produce (mainly leaf lettuce, rocket and spinach) with roughly 15,000 ha and 160 kilotons per year in protected cultivation (http:/ / agri.istat.it). However, the potential effects of biostimulants on yield and especially on nutritional quality of horticultural crops including spinach have been mainly investigated in pot experiments and in soilless conditions, whereas limited information is available concerning their effects on vegetable crop performance in soil culture [9].

Taking into consideration that the biostimulant action of PHs, SWEs and PEs can vary depending on several interacting variables, such as species, product type (fruit vs. leafy vegetables) and growing conditions (soilless vs. soil), a greenhouse experiment was conducted to examine the response of spinach crop to three PBs delivered by foliar application: (a) a legume-derived $\mathrm{PH}$; (b) an extract of seaweed Ecklonia maxima; and (c) a mixture of vegetal oils, herbal and seaweed Ascophyllum nodosum extracts. The response of the spinach crop was assessed in terms of yield, leaf colorimetric components, mineral profile and physicochemical composition of the leaves. 


\section{Materials and Methods}

\subsection{Greenhouse Conditions and Plant Material}

The experiment was carried out in the 2017 growing season from $20^{\text {th }}$ March to $21^{\text {st }}$ April, in an unheated polyethylene greenhouse located at the Department of Agricultural Sciences, University of Naples Federico II, Portici (NA), south of Italy ( $40^{\circ} 49^{\prime} \mathrm{N}, 14^{\circ} 15^{\prime} \mathrm{E} ; 72 \mathrm{~m}$ a.s.1.). The soil was a sandy loam (76\% sand, $17 \%$ silt, $7 \%$ clay), with a $\mathrm{pH}$ of 6.8 , electrical conductivity of $0.64 \mathrm{mS} \mathrm{cm}^{-1}$, organic matter of $1.25 \%(w / w), \mathrm{C}: \mathrm{N}$ of 10.8 , total $\mathrm{N}$ at $0.15 \%$, carbonates at $0.3 \%, \mathrm{NO}_{3}-\mathrm{N}$ and $\mathrm{NH}_{4}-\mathrm{N}$ at 110 and $19 \mathrm{mg} \mathrm{kg}^{-1}$, respectively, $\mathrm{P}$ at $48 \mathrm{mg} \mathrm{kg}^{-1}$, and exchangeable $\mathrm{K}$ at $1080 \mathrm{mg} \mathrm{kg}^{-1}$.

The crop selected for the current greenhouse trial was baby spinach (Spinacia oleracea L.) ‘DONKEY F1' (RijkZwaan, Bologna, Italy). This spinach F1 hybrid is an early semi-savoy baby leaf variety characterized by dark, glossy and oval shape leaves with an upright growth habit. The 'DONKEY F1' was selected as the most representative commercial variety used in Italy during the spring and autumn growing seasons under greenhouse conditions.

\subsection{Experimental Design, Plant Biostimulants Application and Cultural Practices}

Four treatments were derived from the application of four plant biostimulants (PBs): non-treated (control), legume-derived protein hydrolysate (PH), extract of seaweed Ecklonia maxima (SWE), and mixture of vegetal oils, herbal and seaweed Ascophyllum nodosum extracts [VO + SWE]). The area of each experimental unit measured $3.0 \mathrm{~m}^{2}$, with a plant density of 1,000 seeds $\mathrm{m}^{-2}$. Spinach was hand-seeded on March 20th.

The legume-derived protein hydrolysate Trainer ${ }^{\circledR}$ (Italpollina S.p.A., Rivoli Veronese, Italy) is a commercial PB obtained through enzymatic hydrolysis of proteins derived from legume seeds. It contains $50 \mathrm{~g} \mathrm{~kg}^{-1}$ of $\mathrm{N}$ as free amino acids, and soluble peptides [9]. The aminogram of the product in $\mathrm{g} \mathrm{kg}^{-1}$ was: Ala (12), Arg (18), Asp (34), Cys (3), Glu (54), Gly (12), His (8), Ile (13), Leu (22), Lys (18), Met (4), Phe (15), Pro (15), Thr (11), Trp (3), Tyr (11), Val (14). The elemental composition of Trainer ${ }^{\circledR}$ is as follows: $\mathrm{N} 50.0 \mathrm{~g} \mathrm{~kg}^{-1}, \mathrm{P} 0.9 \mathrm{~g} \mathrm{~kg}^{-1}, \mathrm{~K} 4.1 \mathrm{~g} \mathrm{~kg}^{-1}, \mathrm{Ca} 0.7 \mathrm{~g} \mathrm{~kg}^{-1}, \mathrm{Mg} 10.0 \mathrm{~g} \mathrm{~kg}^{-1}, \mathrm{Fe} 30.0 \mathrm{mg} \mathrm{kg}^{-1}$, Mn $1.0 \mathrm{mg} \mathrm{kg}^{-1}$, B $1.0 \mathrm{mg} \mathrm{kg}^{-1}$, Zn $9.6 \mathrm{mg} \mathrm{kg}^{-1}$, and $\mathrm{Cu} 9.0 \mathrm{mg} \mathrm{kg}^{-1}$. The second commercial PB used in the present greenhouse experiment was the SWE Kelpak ${ }^{\circledR}$ (Kelp Products (Pty) Ltd., Cape Town, South Africa). Kelpak ${ }^{\circledR}$ is produced from the brown seaweed Ecklonia maxima (Osbeck) Papenfuss, obtained through a process called 'cold cell burst' (i.e., high pressure and low temperatures). It mainly contains phytohormones (mostly auxins $11 \mathrm{mg} \mathrm{kg}^{-1}$, cytokinins $0.03 \mathrm{mg} \mathrm{kg}^{-1}$ and auxin:cytokinin ratio 367:1), carbohydrates $\left(16.9 \mathrm{~g} \mathrm{~kg}^{-1}\right)$, amino acids $\left(2.5 \mathrm{~g} \mathrm{~kg}^{-1}\right)$, vitamin B1 $\left(0.9 \mathrm{mg} \mathrm{kg}^{-1}\right), \mathrm{B} 2$ $\left(0.1 \mathrm{mg} \mathrm{kg}^{-1}\right), \mathrm{C}\left(20 \mathrm{mg} \mathrm{kg}^{-1}\right)$, and $\mathrm{E}\left(0.7 \mathrm{mg} \mathrm{kg}^{-1}\right)$. The elemental profile of Kelpak ${ }^{\circledR}$ is as follows: $\mathrm{N}$ $3.6 \mathrm{~g} \mathrm{~kg}^{-1}$, P $8.2 \mathrm{~g} \mathrm{~kg}^{-1}$, K $7.2 \mathrm{~g} \mathrm{~kg}^{-1}$, Ca $0.8 \mathrm{~g} \mathrm{~kg}^{-1}$, Mg $0.2 \mathrm{~g} \mathrm{~kg}^{-1}$, Fe $13.6 \mathrm{mg} \mathrm{kg}^{-1}$, Mn $8.4 \mathrm{mg} \mathrm{kg}^{-1}$, B $0.24 \mathrm{mg} \mathrm{kg}^{-1}, \mathrm{Zn} 4.2 \mathrm{mg} \mathrm{kg}^{-1}$, and $\mathrm{Cu} 0.2 \mathrm{mg} \mathrm{kg}^{-1}$ [9]. The third commercial PB was Amalgerol ${ }^{\circledR}$ (Hechenbichler $\mathrm{GmbH}$, Innsbruck, Austria). Amalgerol ${ }^{\circledR}$ contains plant extracts, essential oils and fatty acids in oil/water emulsion, and extract of the seaweed Ascophyllum nodosum. The elemental composition of Amalgerol ${ }^{\circledR}$ is as follows: $\mathrm{N} 5.5 \mathrm{~g} \mathrm{~kg}^{-1}, \mathrm{P} 0.6 \mathrm{~g} \mathrm{~kg}^{-1}$ and $\mathrm{K} 3.6 \mathrm{~g} \mathrm{~kg}^{-1}$ [27]. The three commercial PBs selected are the most frequently used and representative non-animal-derived PBs used in several European countries including Italy.

The PB-treated spinach plants were uniformly sprayed four times during the growing cycle at weekly intervals starting 17 days after sowing (DAS; 5thApril) with a solution containing $3 \mathrm{~mL} \mathrm{~L}^{-1}$ of Trainer $^{\circledR}(\mathrm{PH}), 3 \mathrm{~mL} \mathrm{~L}{ }^{-1} \mathrm{Kelpak}^{\circledR}(\mathrm{SWE})$, and $3 \mathrm{~mL} \mathrm{~L}^{-1}$ Amalgerol ${ }^{\circledR}(\mathrm{VO}+\mathrm{SWE})$ using a 16-L stainless steel sprayer 'Vibi Sprayer' (Volpi, Piadena, Italy). The concentrations of the three commercial PBs used were based on the manufacturers' recommendations as well as on previous published work [21,28,29].

No phosphorus and potassium fertilization were performed due to the high content of these macro elements present in the soil. Nitrogen was applied as ammonium nitrate $\left(34 \% ; 90 \mathrm{~kg} \mathrm{~N} \mathrm{ha}^{-1}\right)$ through the overhead irrigation system at 7, 14 and 21 DAS. During the growing season, spinach 
plants were kept free from pathogens, pests and weeds according to the standard practices adopted among greenhouse leafy vegetable growers in Italy.

\subsection{Sampling, Yield and Growth Assessments}

Spinach plants were harvested on 28 April (40 DAS) and fresh yield was determined in sampling of one square meter from the center of each experimental plot. Spinach leaves were dried at $70{ }^{\circ} \mathrm{C}$ for $72 \mathrm{~h}$ until they reached a constant weight to determine the corresponding dry biomass. Fresh yield as well as leaf dry biomass were expressed in $\mathrm{kg} \mathrm{m}^{-2}$. The number of leaves per plant as well as the total leaf area were recorded on 15 plants per experimental unit. The total leaf area per plant was also measured using an electronic area meter (Li-Cor3000, Li-Cor, Lincoln, NE, USA).

For the determination of nitrate content, mineral profile, total phenolics and ascorbic acid contents, samples of fresh matter from randomly selected baby spinach were instantly frozen in liquid nitrogen and stored at $-80^{\circ} \mathrm{C}$ until phytochemical analysis.

\subsection{Leaf Color Measurements}

The Soil Plant Analysis Development (SPAD) index was measured on fully expanded spinach leaves by means of a portable chlorophyll meter SPAD-502 (Konica Minolta, Tokyo, Japan) twice during the growing cycle, at 25 and 39 DAS. Twenty healthy and fully expanded leaves were randomly measured and averaged to a single SPAD value for each experimental plot. Just before harvesting, baby spinach color was measured at the upper leaf surface using an $8 \mathrm{~mm}$-aperture Minolta CR-300 Chroma Meter (Minolta Camera Co. Ltd., Osaka, Japan) calibrated with a Minolta standard white plate before measurements were performed. Measurements were obtained in the Commission internationale de l'éclairage CIELAB color space parameters: $L^{*}$ (lightness, ranging from $0=$ black to $100=$ white), $a^{*}$ [chroma component ranging from green $(-60)$ to red $(+60)], \mathrm{b}^{*}$ [chroma component ranging from blue $(-60)$ to yellow $(+60)]$.

\subsection{Dry matter, Protein, Nitrate and Mineral Content Analysis}

The leaf dry matter percentage was determined in triplicates as a percentage of fresh mass following leaf desiccation to constant weight in a forced-air oven at $70^{\circ} \mathrm{C}$ for $72 \mathrm{~h}$, and weighed using an analytical balance (Denver Instruments, Denver, Colorado, CO USA). The total protein content was assessed by the Kjeldahl method [30], with nitrogen to protein conversion factor of 6.25 .

Leaf dry tissues were ground in a Wiley Mill to pass through an 841-microns screen, baby spinach plants were assayed for concentrations of $\mathrm{NO}_{3}-\mathrm{N}$ and the following macro elements: $\mathrm{P}, \mathrm{K}, \mathrm{Ca}, \mathrm{Mg}$ and Na. Briefly, $250 \mathrm{mg}$ of finely ground dried tissues were suspended in $50 \mathrm{~mL}$ of ultrapure water (Milli-Q, Merck Millipore, Darmstadt, Germany) and subjected to three freeze-thaw cycles in liquid nitrogen followed by shaking water bath (ShakeTemp SW22, Julabo, Seelbach, Germany) at $80^{\circ} \mathrm{C}$ for $10 \mathrm{~min}$. The mixture was centrifuged at $6000 \mathrm{rpm}$ for $10 \mathrm{~min}\left(\mathrm{R}^{-1} 0 \mathrm{M}\right.$, Remi Elektrotechnik Limited, India), then filtered through a $0.20 \mu \mathrm{m}$ filter paper (Whatman International Ltd., Maidstone, UK.), as described previously by Rouphael et al. [20]. Potassium, $\mathrm{Ca}, \mathrm{Mg}$ and Na were separated by ion chromatography (ICS-3000, Dionex, Sunnyvale, CA, USA) and quantified through an electrical conductivity detector. Chromatographic separation was achieved in isocratic mode on an IonPac CS12A analytical column $(4 \times 250 \mathrm{~mm}$, Dionex, Corporation) equipped with an IonPac CG12A precolumn $(4 \times 250 \mathrm{~mm}$, Dionex, Corporation) and a self-regenerating suppressor CERS500 (4 mm, Dionex, Corporation). The nitrate and phosphorus contents were also quantified through ion chromatography coupled to a conductivity detector. An IonPac ATC-HC anion trap $(9 \times 75 \mathrm{~mm})$, and a AS11-HC analytical column $(4 \times 250 \mathrm{~mm})$ equipped with an AG11-HC precolumn $(4 \times 50 \mathrm{~mm})$ and a self-regenerating suppressor AERS500 $(4 \mathrm{~mm})$ were used for separation. Nitrate was expressed as $\mathrm{mg} \mathrm{kg}^{-1}$ fresh weight on the basis of each sample's original dry matter content, while $\mathrm{P}, \mathrm{K}, \mathrm{Ca}, \mathrm{Mg}$ and $\mathrm{Na}$ were expressed as $\mathrm{g} \mathrm{kg}^{-1}$ dry weight. 


\subsection{Phenolics and Ascorbic Acid Analysis}

The total phenols content in methanolic extracts was assessed using the Folin-Ciocalteu method [31] with gallic acid as a standard. Briefly, $100 \mathrm{~mL}$ aliquot of the supernatant was combined with $500 \mathrm{~mL}$ of Folin-Ciocalteau's reagent (Sigma-Aldrich Inc., Milano, Italy) and $400 \mathrm{~mL}$ of $7.5 \%$ sodium carbonate/water $(w / v)$. The absorbance of the solution was measured after $30 \mathrm{~min}$ at $765 \mathrm{~nm}$ by using an ultraviolet-visible spectrophotometer, and the result was expressed as mg gallic acid (Sigma-Aldrich Inc.) per $100 \mathrm{~g}$ of dry weight.

The total ascorbic acid was also assessed by spectrophotometric detection as described by Kampfenkel et al. [32]. Briefly, the dehydroascorbate is reduced to ascorbic acid by pre-incubation of the sample with dithiothreitol. The absorbance of the solution was measured at $525 \mathrm{~nm}$, and the results were expressed as $\mathrm{mg}$ ascorbic acid on $100 \mathrm{~g}$ fresh weight.

\subsection{Statistical Analysis}

Analysis of variance (one way-ANOVA) of the experimental data was performed using the IBM SPSS Statistics 20 software package. To separate treatment means within each measured parameter, the Duncan's Multiple Range Test was performed at $p \leq 0.05$. Yield and growth performance characteristics, leaf colorimetry, mineral composition and bioactive phytochemical content of non-treated and PB-treated plants were subjected to Principal Component Analysis (PCA) to explore relationships among variables and treatments and to determine which yield and quality traits were the most effective in discriminating between PB application treatments. The PCA outputs include variable loading to each selected component and treatment component scores. Principal component analysis was carried out using function 'PCA' from the IBM SPSS Statistics 20 software package.

\section{Results and Discussion}

\subsection{Implications of PBs Application on Yield and Morphological Parameters}

The fresh yield at harvest was significantly affected by the plant biostimulant $(\mathrm{PB}=$ treatments (Table 1$)$. The foliar application at $3 \mathrm{~mL} \mathrm{~L}^{-1}$ of legume-derived protein hydrolysate (PH), extract of seaweed Ecklonia maxima (SWE) or mixture of vegetal oils, herbal and seaweed Ascophyllum nodosum-based extracts (VO + SWE) induced a significant increase in fresh yield (by $51.5 \%$ on average) over untreated plants with no significant difference between the three commercial PB treatments (Table 1 and Figure 1). Interestingly, the higher spinach fresh yield observed in PB-treated plants in comparison to the control treatment was due to an increase in the leaf area and not in the number of leaves per plant (Table 1). In fact, irrespective of PB origin, the mean total leaf area obtained in treated plants was significantly higher than that in untreated ones with a respective increase by $12 \%$ (Table 1 ). Similar to the effects on fresh yield, the leaf dry biomass in PB-treated plants was significantly higher (by $53 \%$ on average) than that obtained in untreated spinach plants irrespective of the biostimulant treatments (Table 1).

Table 1. The effect of biostimulant treatments on fresh yield, dry biomass, leaf number and total area of greenhouse spinach plants.

\begin{tabular}{|c|c|c|c|c|}
\hline Biostimulant & Yield $\left(\mathrm{kg} \cdot \mathrm{m}^{-2}\right)$ & Leaf Dry Weight $\left(\mathrm{kg} \cdot \mathrm{m}^{-2}\right)$ & Leaf Number (no. plant ${ }^{-1}$ ) & Leaf Area $\left(\mathrm{cm}^{2}\right.$ plant $\left.{ }^{-1}\right)$ \\
\hline Control & $1.45 \mathrm{c}$ & $0.10 \mathrm{~b}$ & 5.0 & $97.2 \mathrm{~b}$ \\
\hline Legume-derived protein hydrolysate & $2.29 \mathrm{a}$ & $0.16 \mathrm{a}$ & 5.2 & $115.8 \mathrm{a}$ \\
\hline Seaweed extract of E. maxima & $2.22 \mathrm{a}$ & $0.15 \mathrm{a}$ & 4.9 & $112.5 \mathrm{a}$ \\
\hline Vegetal oils, herbal extracts and A. nodosum-based extract & $2.08 \mathrm{a}$ & $0.15 \mathrm{a}$ & 5.1 & $111.9 \mathrm{a}$ \\
\hline Significance $^{\mathrm{z}}$ & * & * & NS & ** \\
\hline
\end{tabular}

${ }^{\mathrm{Z}} \mathrm{NS},{ }^{*},{ }^{* *}$ Non-significant or significant at $p<0.05$ or $p<0.01$, respectively. Different letters within each column indicate significant differences according to Duncan's multiple range test $p<0.05$. 


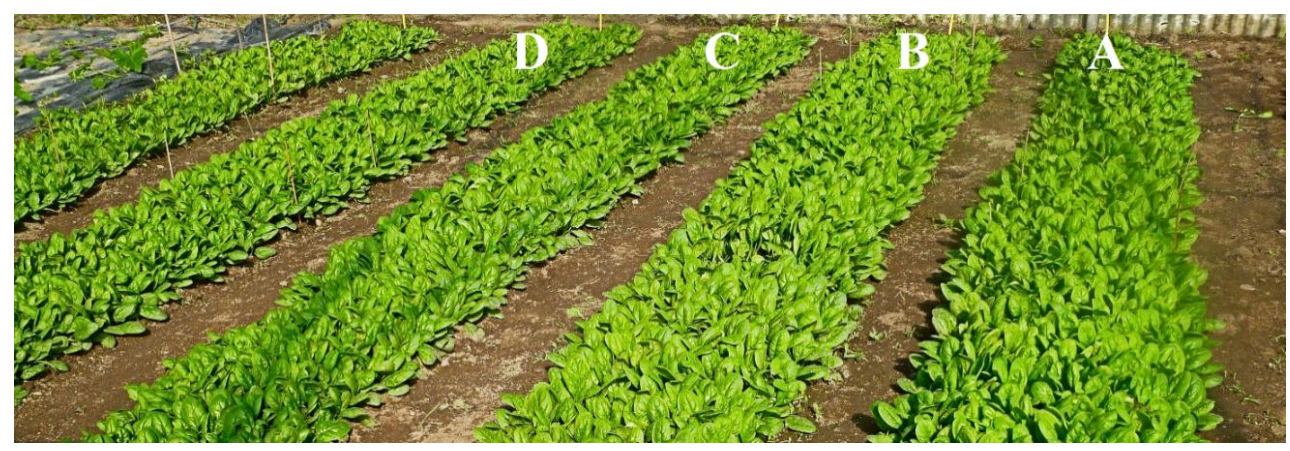

Figure 1. Spinach plots in the experimental trial $(\mathbf{A}=$ legume-derived protein hydrolysate; $\mathbf{B}=$ extract of seaweed Ecklonia maxima; $\mathbf{C}=$ control; $\mathbf{D}=$ mixture of vegetal oils, herbal and seaweed Ascophyllum nodosum extracts).

The increase in yield and growth performance characteristics of spinach plants grown under soil conditions has been reported in a recent research study testing the actions of three commercial PBs (tropical plant extract, seaweed extract E. maxima and legume-derived protein hydrolysate) on greenhouse fresh tomato [9]. However, the stimulation effect (higher fresh yield by $51.5 \%$ ) recorded in the current experiment was far higher than those recorded on both early and marketable yields of fresh tomato (14-30\% and 7-12\%, respectively; [9]) indicating crop-specific differential response to biostimulant treatments and therefore warranting additional crop-specific research to optimize biostimulants application [33].

Our findings on the beneficial foliar application of brown seaweed extracts with E. maxima or A. nodosum were consistent with the results of Colla et al. [9] and Ali et al. [34] who demonstrated that the foliar application of E. maxima $\left(3 \mathrm{~mL} \mathrm{~L}^{-1}\right)$ or $A$. nodosum $(0.5 \%)$ improved the tomato crop productivity compared to untreated control. Both research groups attributed the higher plant productivity to the major components of commercial seaweed extracts (30-40\% of the extract on dry weight basis), such as polysaccharides (alginates, fucoidan and laminarins), which are well known for triggering endogenous hormone homeostasis [35,36].

As with the applications of E. maxima seaweed extract or of the mixture of vegetal oils, herbal extracts and seaweed extract of $A$. nodosum, spinach plants treated with legume-derived $\mathrm{PH}$ incurred increased fresh yield by $53 \%$. A presumed mechanism behind the plant-growth stimulation effect is the presence of signaling molecules such as small peptides which are typical components of the commercial PH Trainer ${ }^{\circledR}$ used in the current experiment. The bioactive peptides in the Trainer ${ }^{\circledR}$ formulation could act as elicitors since they are easily received by both leaf and root, thus may have triggered a signal transduction pathway through modulation of endogenous phytohormone biosynthesis (auxin- and/or gibberellin-like activities; [28,37]) thus boosting crop yield. Another putative mode of action behind the stimulation effect of legume-derived $\mathrm{PH}$ on fresh yield is the modulation of the root system architecture in particular the increase in root hair length and density [38], which may improve $\mathrm{N}$ use efficiency, thus boosting total fresh and dry biomasses.

\subsection{Implications of PBs Application on SPAD index and Leaf Colorimetry}

Among the physical properties of vegetable species that significantly influence consumer preference is the colorimetric CIELAB components in particular brightness $\left(L^{*}\right)$, redness $\left(a^{*}\right)$ and yellowness $\left(b^{*}\right)$ [39]. In the current study, neither the application with legume-derived $\mathrm{PH}$ nor biostimulant treatment with E. maxima or vegetable oils, herbal extracts in addition to A. nodosum had a significant effect on $L^{*}$ (average 42.2), $a^{*}$ (average -15.2 ), or $b^{*}$ (average 21.5) parameters (Table 2). However, the SPAD index values, widely used as a non-invasive and non-destructive estimate of chlorophyll content were highly influenced biostimulant treatments (Table 2). For instance, SPAD index values were higher by $15.6 \%$ and $18.6 \%$ at 25 and 39 DAS, respectively, in the three biostimulant 
treatments (average 37.5 and 35.8, respectively) compared to untreated spinach plants (32.5 and 30.2, respectively; Table 2). These findings have been observed in a wide range of horticultural crops including tomato, spinach, lettuce, melon treated with biostimulants of different origin including amino acids, protein hydrolysate as well as plant and seaweed extracts $[7,13,18,26,38-41]$. The higher SPAD index values observed in spinach plants treated with biostimulants ( $\mathrm{PH}, \mathrm{SWE}$ or VO + SWE) could be also considered a mechanism by which biostimulant application can promote $\mathrm{N}$ uptake efficiency. In fact, SPAD index is widely considered as a key indicator of chlorophyll biosynthesis and photosynthetic apparatus functioning, that contributed to the translocation of photosynthates (i.e., soluble sugars) via the phloem from sources to the sinks, thus boosting crop performance [2,37].

Table 2. The effect of biostimulant treatments on the Soil Plant Analysis Development (SPAD) index and Hunter color parameters $\mathrm{L}^{*}$ (brightness), $\mathrm{a}^{*}\left(+\mathrm{a}^{*}=\right.$ red; $-\mathrm{a}^{*}=$ green $)$ and $\mathrm{b}^{*}\left(+\mathrm{b}^{*}=\right.$ yellow; $-\mathrm{b}^{*}=$ blue $)$ of leaves in greenhouse spinach plants.

\begin{tabular}{|c|c|c|c|c|c|}
\hline \multirow{2}{*}{ Biostimulant } & \multicolumn{2}{|c|}{ SPAD } & \multirow{2}{*}{$\mathbf{L}$} & \multirow{2}{*}{$a^{*}$} & \multirow{2}{*}{$\mathbf{b}^{*}$} \\
\hline & 25 DAS & 39 DAS & & & \\
\hline Control & $32.5 \mathrm{~b}$ & $30.2 \mathrm{~b}$ & 43.0 & -15.3 & 21.7 \\
\hline Legume-derived protein hydrolysate & $37.5 \mathrm{a}$ & $35.9 \mathrm{a}$ & 41.0 & -15.7 & 22.4 \\
\hline Seaweed extract of E. maxima & $37.1 \mathrm{a}$ & $36.2 \mathrm{a}$ & 42.7 & -14.9 & 21.1 \\
\hline Vegetal oils, herbal extracts and A. nodosum-based extract & $38.1 \mathrm{a}$ & $35.4 \mathrm{a}$ & 42.2 & -14.8 & 20.9 \\
\hline Significance $\mathrm{z}$ & $* * *$ & $* *$ & NS & NS & NS \\
\hline
\end{tabular}

$\mathrm{z}_{\mathrm{NS},{ }^{* *},{ }^{* * *} \text { Non-significant or significant at } p<0.01 \text { or } 0.001 \text {, respectively. Different letters within each column }}$ indicate significant differences according to Duncan's multiple range test $p<0.05$. DAS, days after sowing.

\subsection{Implications of PBs Application on Protein, Mineral Profile and Nitrate Content}

No significant differences between the four biostimulant foliar applications were recorded for the leaf dry matter percentage (average $6.8 \%$ ), whereas the protein content was highly influenced by the biostimulant treatments, which was higher by $12.4 \%$ in treated (average $32.8 \mathrm{~g} \mathrm{~kg}^{-1} \mathrm{dw}$ ) than in untreated (average $29.2 \mathrm{~g} \mathrm{~kg}^{-1} \mathrm{dw}$ ) spinach plants (Table 3). The highest protein content in PB-treated plants has been frequently associated with better $\mathrm{N}$ uptake and translocation [42]. Our findings were also confirmed by the significant correlation $(p<0.05)$ observed between SPAD index and total leaf N content (Pearson's coefficient 0.961 ; data not shown).

Concerning the implications of PBs effect on plant mineral profile, it is well established that major minerals in the diet are important to avoid nutritional disorders and disease symptoms due to their well-known potentials and functionalities in the body homeostasis and metabolism [43]. Levander [44] reported that the contribution of fruits and vegetables to dietary intake of $\mathrm{P}, \mathrm{K}, \mathrm{Ca}, \mathrm{Mg}$ and $\mathrm{Na}$ is $11 \%, 35 \%, 7 \%, 24 \%$ and $11 \%$, respectively. Among the macro-minerals studied $\mathrm{K}$ was by far the most abundant constituent irrespective of the biostimulant treatments ranging from 67.5 to $92.1 \mathrm{~g} \mathrm{~kg}^{-1} \mathrm{dw}$, followed by Ca (12.1-13.5 $\left.\mathrm{g} \mathrm{kg}^{-1} \mathrm{dw}\right), \mathrm{Mg}\left(7.2-9.0 \mathrm{~g} \mathrm{~kg}^{-1} \mathrm{dw}\right), \mathrm{P}\left(3.3-3.7 \mathrm{~g} \mathrm{~kg}^{-1} \mathrm{dw}\right)$ and inally $\mathrm{Na}$ (1.2-1.7 $\mathrm{g} \mathrm{kg}^{-1} \mathrm{dw}$ ) (Table 3). Our findings are in line with those of Colonna et al. [45], who reported that $\mathrm{K}$ was the predominant macronutrient present in baby spinach under greenhouse conditions.

The concentrations of nutrients in cultivated baby spinach revealed significant differences among biostimulant treatments for $\mathrm{K}, \mathrm{Mg}$ and $\mathrm{Na}$, whereas no significant effects among foliar biostimulant applications were recorded for $\mathrm{P}$ (average $3.5 \mathrm{~g} \mathrm{~kg}^{-1} \mathrm{dw}$ ) and $\mathrm{Ca}$ (average $12.5 \mathrm{~g} \mathrm{~kg}^{-1} \mathrm{dw}$ ) (Table 3). For instance, our results showed that foliar application of legume-derived $\mathrm{PH}$ Trainer ${ }^{\circledR}$ elicited significant increase (36.4\% and $25.0 \%$ ) of $\mathrm{K}$ and $\mathrm{Mg}$ contents compared to untreated plants, whereas foliar spray treatment with SWE and VO + SWE exhibited intermediate values (Table 3). Interestingly, a very low $\mathrm{Na} / \mathrm{K}$ ratio (average 0.014 ) in PB-treated plants was recorded in comparison to untreated spinach (0.025). The lowest ratio observed in treated spinach is important from a nutritional point of view, as diets with low $\mathrm{Na} / \mathrm{K}$ ratio are correlated with lower incidence of heart attacks and hypertension [46]. The better nutritional status recorded in legume-derived PH plants has been 
observed previously on fruit vegetables such as tomato grown under greenhouse conditions [9]. Our findings indicated that the increased 'nutrient acquisition response' (higher $\mathrm{K}$ and $\mathrm{Mg}$ ) may be associated to several modes of action like: (i) the presence of signaling molecules in the $\mathrm{PH}$ product, such as free amino acids and soluble peptides [2,16]; (ii) the greater uptake, translocation and accumulation of nutrients effecting stimulation of the root system architecture [18,28]; and (iii) the expression of genes encoding for macronutrients transporters in cell membranes [37,47].

Table 3. The effect of biostimulant treatments on dry matter percentage, protein content, and mineral concentration of leaves in greenhouse spinach plants.

\begin{tabular}{|c|c|c|c|c|c|c|c|}
\hline \multirow{2}{*}{ Biostimulant } & \multirow{2}{*}{$\begin{array}{c}\text { Dry Matter } \\
(\%)\end{array}$} & \multirow{2}{*}{$\begin{array}{c}\text { Protein } \\
\left(\mathrm{g} \cdot \mathrm{kg}^{-1} \mathrm{dw}\right)\end{array}$} & \multicolumn{5}{|c|}{ Mineral Elements $\left(\mathrm{g} \cdot \mathrm{kg}^{-1} \mathrm{dw}\right)$} \\
\hline & & & $\mathbf{P}$ & $\mathbf{K}$ & $\mathrm{Ca}$ & Mg & $\mathbf{N a}$ \\
\hline Control & 6.7 & $29.2 \mathrm{~b}$ & 3.6 & $67.5 \mathrm{c}$ & 12.3 & $7.2 \mathrm{c}$ & $1.7 \mathrm{a}$ \\
\hline Legume-derived protein hydrolysate & 6.8 & $32.4 \mathrm{a}$ & 3.7 & $92.1 \mathrm{a}$ & 12.3 & $9.0 \mathrm{a}$ & $1.3 \mathrm{~b}$ \\
\hline Seaweed extract of E. maxima & 6.8 & $32.5 \mathrm{a}$ & 3.3 & $82.9 \mathrm{~b}$ & 12.1 & $8.7 \mathrm{~b}$ & $1.4 \mathrm{ab}$ \\
\hline Vegetal oils, herbal extracts and A. nodosum-based extract & 6.9 & $33.6 \mathrm{a}$ & 3.3 & $86.6 \mathrm{ab}$ & 13.5 & $8.6 \mathrm{~b}$ & $1.2 \mathrm{~b}$ \\
\hline Significance $\mathrm{z}$ & NS & $* *$ & NS & $* * *$ & NS & $* * *$ & * \\
\hline
\end{tabular}

${ }_{\mathrm{Z} S},{ }^{*}{ }^{* *},{ }^{* * *}$ Non-significant or significant at $p<0.05, p<0.01$ or $p<0.001$, respectively. Different letters within each column indicate significant differences according to Duncan's multiple range test $p<0.05$.

From a botanical point of view, spinach, which belongs to the Chenopodiaceae family, is normally considered a nitrate-accumulating leafy vegetable species [48]. Nitrate content was significantly $(p<0.01)$ influenced by biostimulant applications with the highest values recorded in both SWE and $\mathrm{VO}+\mathrm{SWE}$ treatments (3227 and $3485 \mathrm{mg} \mathrm{kg}^{-1} \mathrm{fw}$, respectively; Figure 2). Because the maximum level set by EC Regulation No 1258/2011 for fresh spinach is $3500 \mathrm{mg} \mathrm{kg}^{-1} \mathrm{fw}$, the spinach treated with PB can be marketed in European Union. Interestingly, the nitrate content in legume-derived PH-treated plants was lower than in plants treated with the other $\mathrm{PB}$, and it was not significantly different from the control (2379 and $2040 \mathrm{mg} \mathrm{kg}^{-1} \mathrm{fw}$, respectively; Figure 2). The ability of $\mathrm{PH}$ containing free amino acids and peptides to avoid accumulation of nitrates in leaf tissue could be associated to an up-regulation of the key nitrogen assimilation genes like nitrate reductase, thus contributing to a higher assimilation of nitrates into amino acids [49].

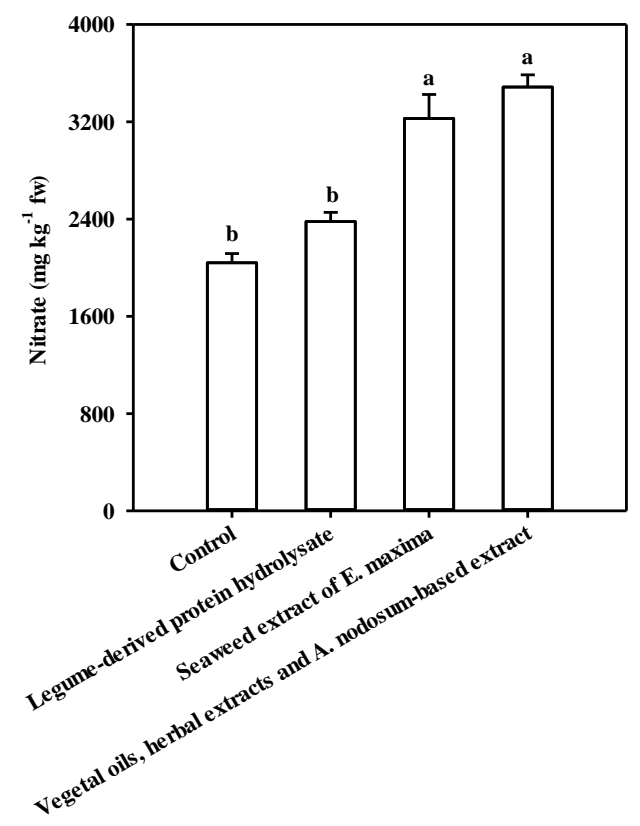

Figure 2. The effect of biostimulant treatments on leaf nitrate content of greenhouse spinach plants. The values are means of three replicates. Vertical bars indicate \pm SE of means. Different letters indicate significant differences according to Duncan's test $(p<0.05)$. 


\subsection{Implications of PBs Application on Phenolics and Ascorbic Acid Content}

Spinach has been always considered as one of the most important leafy greens due to the high antioxidant activity as well as the large quantities of bioactive compounds (phenolics, ascorbate, carotenoids and tocopherols) it contains [50]. Foliar application of Trainer ${ }^{\circledR}$ and Amalgerol ${ }^{\circledR}$ elicited significant increase $(30.7 \%)$ of phenolics compared to untreated plants, whereas foliar spray treatment with SWE of E. maxima exhibited intermediate values (Figure 3).

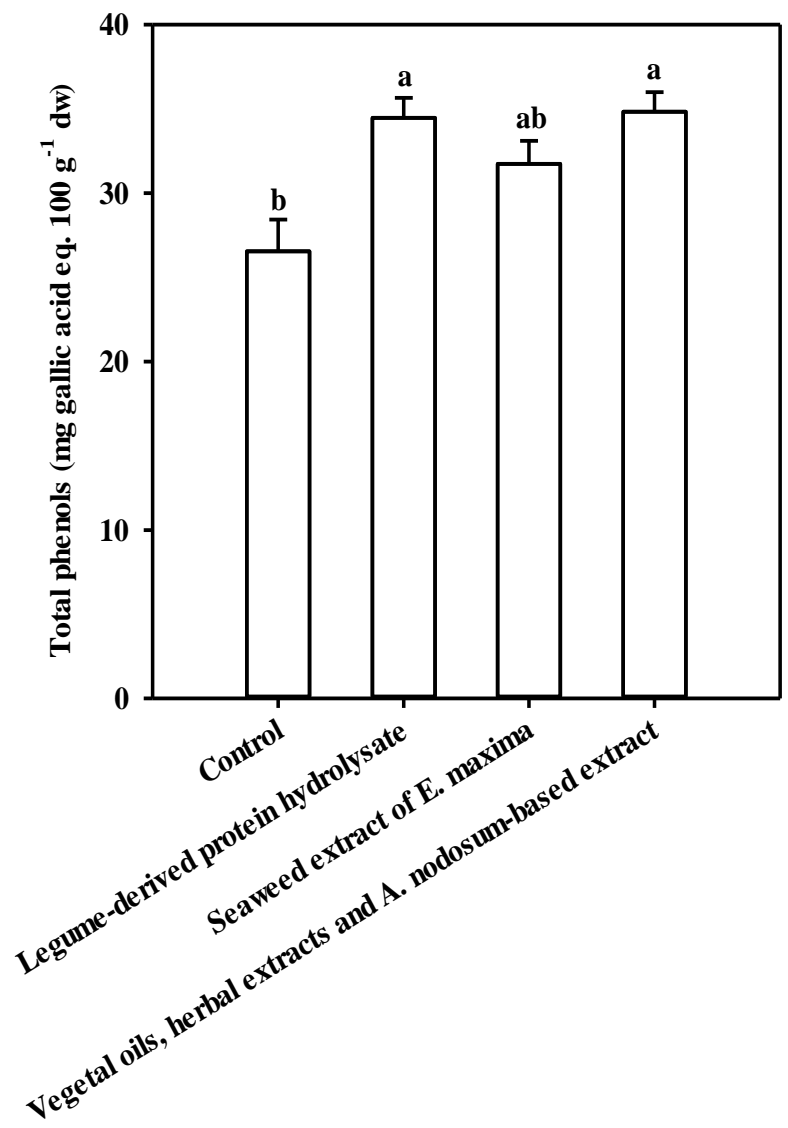

Figure 3. The effect of biostimulant treatments on total phenols content of leaves in greenhouse spinach plants. The values are means of three replicates. Vertical bars indicate $\pm \mathrm{SE}$ of means. Different letters indicate significant differences according to Duncan's test $(p<0.05)$.

As with total polyphenols content, the total ascorbic acid content was highly affected by biostimulant treatment. Compared to untreated spinach plants, total ascorbic content was enhanced by $79.1 \%$ in PB-treated spinach plants, with no significant differences recorded between the three commercial biostimulant applications (Figure 4). 


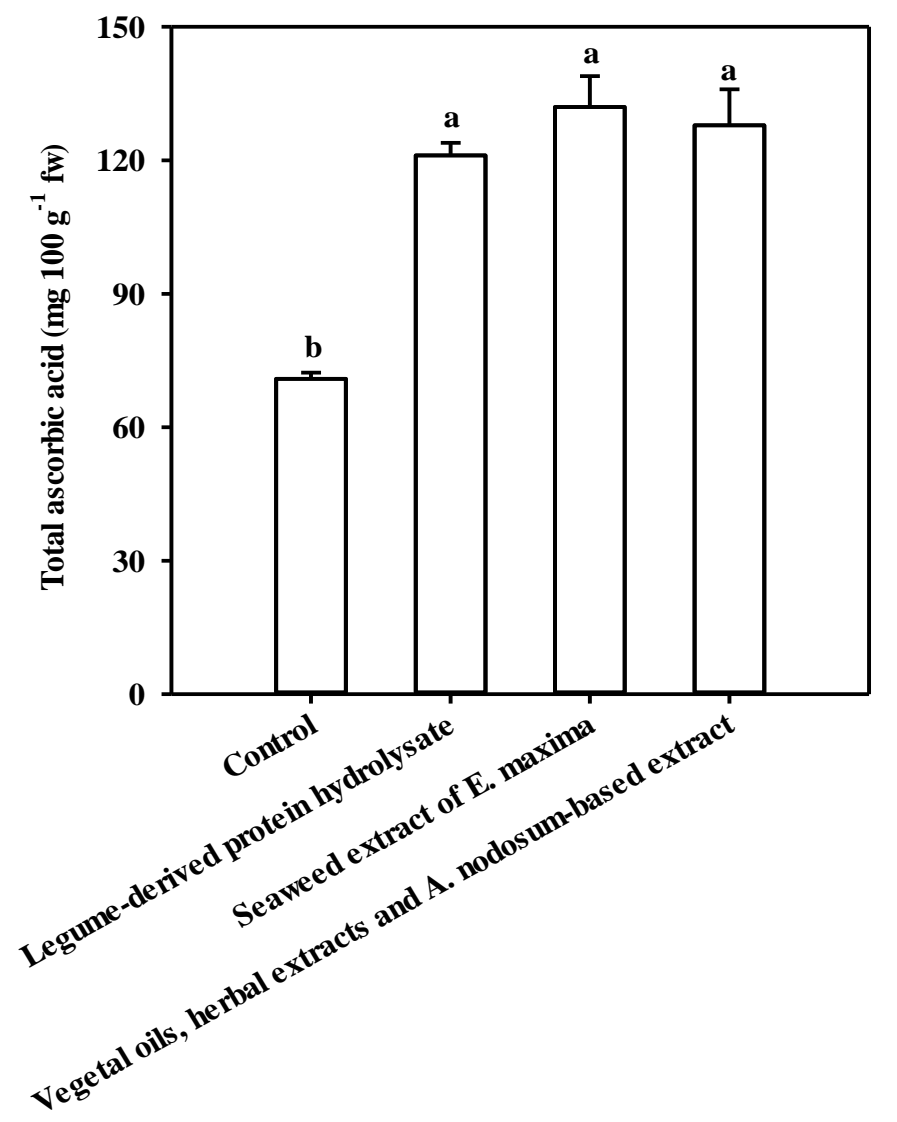

Figure 4. The effect of biostimulant treatments on ascorbic acid content of leaves in greenhouse spinach plants. The values are means of three replicates. Vertical bars indicate $\pm \mathrm{SE}$ of means. Different letters indicate significant differences according to Duncan's test $(p<0.001)$.

The synthesis and accumulation of these secondary metabolites (total phenols and ascorbic acid) could be associated to the activity of key enzymes involved in phytochemical homeostasis (direct effect) as reported by Ertani et al. [26] and Rouphael et al. [3] as well as changes in nutritional status ( $\mathrm{K}$ and $\mathrm{Mg}$; indirect effect) which may positively affect the synthesis and accumulation of antioxidant molecules in vegetables [20]. Our data were in line with previous research on $\mathrm{PH}$ conducted by Ertani and co-workers [26], in which foliar application with alfalfa-derived and red-grape products based biostimulants had higher p-coumaric, chlorogenic acid and capsaicin in green and red greenhouse pepper fruits. Similarly, pre-harvest root treatment of spinach with commercial extract of brown seaweed $A$. nodosum at 1 and $5 \mathrm{~g} \mathrm{~L}^{-1}$ showed a $50 \%$ and $20 \%$ increase in flavonoids as compared to untreated plants [25]. The increase in the bioactive compounds could be mediated through the mechanism involving the stimulation of key enzymes, like chalcone isomerase involved in the biosynthesis of flavanone precursors [41]. Overall, the incurred synthesis and accumulation of phytochemical compounds in leafy vegetables such as spinach could be considered an added value to human diet in support of health and longevity [51].

\subsection{Principal Component Analysis}

To provide a broad overview on the morphometric traits as well as on nutritional and functional quality of greenhouse spinach in response to biostimulant applications of legume-derived PH, SWE of E. maxima and mixture of vegetal oils, herbal extracts and SWE of $A$. nodosum the principal component analysis (PCA) was conducted. Based on our experimental data, the first three principal components (PCs) were associated with Eigenvalues higher than one and accounted for $100 \%$ of the total variance, with PC1, PC2 and PC3 accounting for $73.5 \%, 17.7 \%$ and $8.8 \%$, respectively (Table 4). PC1 was 
positively correlated with yield, dry biomass, SPAD index, total phenols and ascorbic acid, protein, leaf dry matter, and mineral composition $(\mathrm{K}, \mathrm{Ca}$ and $\mathrm{Mg}$ ); it was negatively correlated with Na content. PC2 was positively associated with $\mathrm{Ca}$ and $\mathrm{L}^{*}$ and negatively correlated with phosphorus content (Table 4).

Table 4. Eigenvalues, relative and cumulative percentage of total variance, and correlation coefficients for each spinach trait with respect to the two principal components (PC1 and PC2).

\begin{tabular}{lccc}
\hline Principal Components & PC1 & PC2 & PC3 \\
\hline Eigen value & 10.2 & 2.4 & 1.2 \\
Relative variance (\%) & 73.5 & 17.7 & 8.8 \\
Cumulative variance (\%) & 73.5 & 91.2 & 100 \\
Eigen vectors & & & \\
Protein & $\mathbf{0 . 9 9 0}$ & 0.134 & -0.047 \\
Total ascorbic acid & $\mathbf{0 . 9 7 0}$ & 0.009 & 0.244 \\
Phenols & $\mathbf{0 . 9 6 6}$ & -0.120 & -0.229 \\
SPAD index & $\mathbf{0 . 9 5 5}$ & -0.167 & 0.244 \\
Na & $\mathbf{- 0 . 9 4 6}$ & -0.132 & 0.295 \\
Dry biomass & $\mathbf{0 . 9 4 3}$ & -0.187 & 0.275 \\
Mg & $\mathbf{0 . 9 4 0}$ & -0.321 & 0.114 \\
K & $\mathbf{0 . 9 2 7}$ & -0.356 & -0.120 \\
Yield & $\mathbf{0 . 9 2 1}$ & -0.218 & 0.324 \\
Dry matter percentage & $\mathbf{0 . 9 0 9}$ & 0.311 & -0.279 \\
Nitrate & $\mathbf{0 . 7 7 2}$ & 0.602 & 0.204 \\
P & -0.457 & $-\mathbf{0 . 8 4 2}$ & -0.286 \\
L & -0.569 & $\mathbf{0 . 7 0 9}$ & 0.416 \\
Ca & 0.448 & $\mathbf{0 . 6 5 1}$ & $-\mathbf{0 . 6 1 3}$ \\
\hline
\end{tabular}

Boldface factor loadings indicate the most relevant characters for each principal component.

Concerning the correlation among morphometric and physicochemical quality traits Figure 5 showed that $\mathrm{K}$ was more closely aligned with $\mathrm{Mg}$ content and variation in total phenols was more strongly associated with total ascorbic acid (two vectors with an angle less than 90) (Figure 5).

The effectiveness of PCA in elucidating the effects of genetic materials and several pre and postharvest factors on productivity and especially on quality parameters of several horticultural crops has been documented in several greenhouse and open-field studies $[9,20,45,52,53]$. This was also the case in the current study, since the score plot of the PCA clearly divided the PB-treated and untreated plants along PC1 with biostimulant treatments concentrating most of the morphometric (yield and dry biomass) and physicochemical parameters (leaf dry matter, protein, total phenols and ascorbic acid as well as K, Ca and Mg contents (Figure 5). The upper right quadrant (the positive side of PC1) included plants treated with legume-derived $\mathrm{PH}$ representing spinach with high productivity (on fresh and dry basis) and premium quality in terms of bioactive compounds and especially high $\mathrm{K}$ and $\mathrm{Mg}$ concentrations and lower nitrate level (Figure 5). A second group clustered in the lower right quadrant included plants treated with both SWE of E. maxima and vegetal oils, herbal extracts and seaweed extract of $A$. nodosum characterized by leaf spinach having good concentration of ascorbic acid and protein but on the other hand high nitrate concentration (Figure 5). Finally, the untreated spinach plants had the lowest nutritional quality among treatments (Figure 5). 


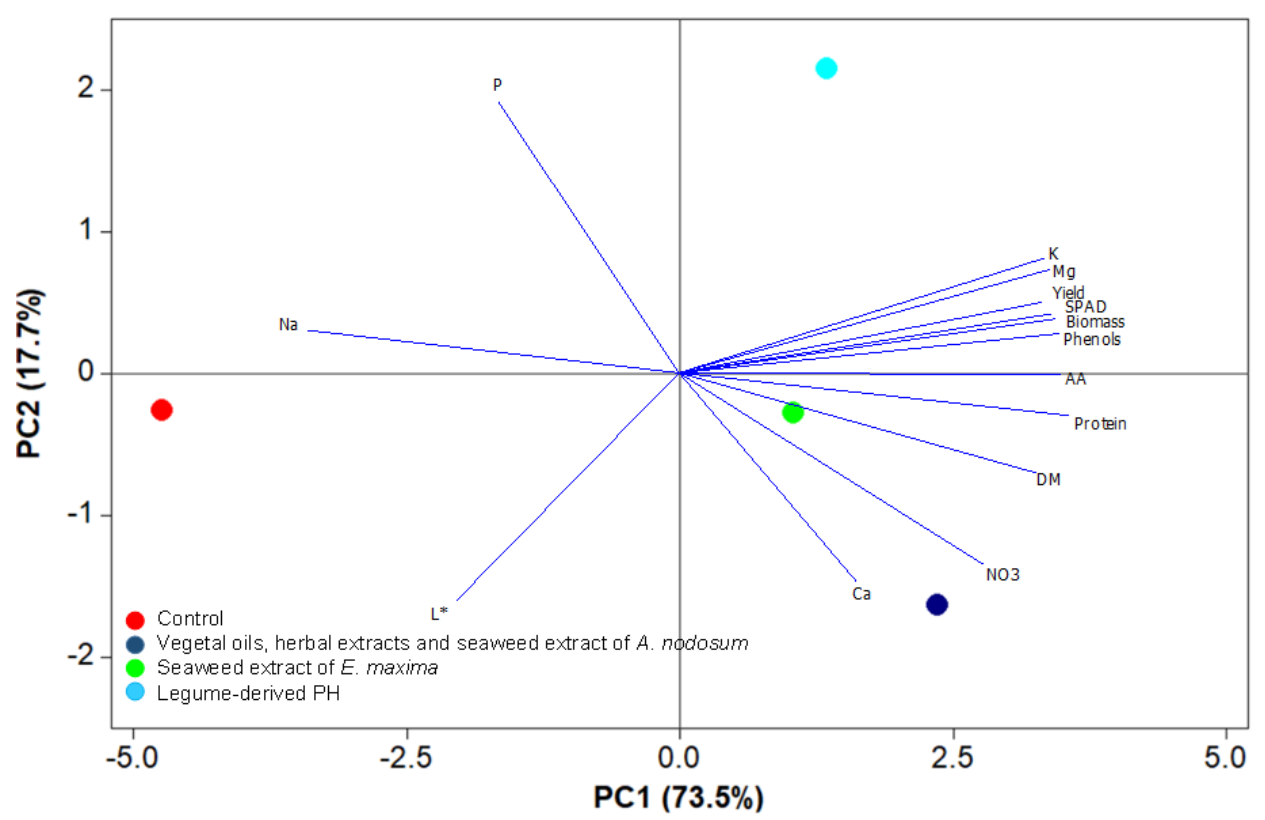

Figure 5. Principal component loading plot and scores of principal component analysis (PCA) of morphometric and quality traits of greenhouse spinach in response to four biostimulant treatments. AA, total ascorbic acid; DM, leaf dry matter percentage.

\section{Conclusions}

The constant pressure on greenhouse leafy vegetable growers to maximize yield along with the increasing demand of consumers and the agro-food industry for produce of premium quality pose an important challenge for extension specialists and researchers in their search for sustainable means to combine maximal production with optimal quality. Plant biostimulants constitute a strategic tool in this effort. The three biostimulants treatments presently assessed enhanced productivity on both fresh and dry weight basis of greenhouse spinach. The foliar application of plant biostimulants was effective in supporting higher chlorophyll biosynthesis and better mineral status for the plants thus leading to a higher crop performance. Our results also demonstrated that the nutritional value of spinach in terms of bioactive compounds and mineral profile can be enhanced by biostimulant action, especially with legume-derived $\mathrm{PH}$ treatment which delivered leaves of high $\mathrm{K}$ and $\mathrm{Mg}$ contents. Legume-derived PH treatment did not enhance the nitrate content of spinach leaves whereas foliar applications of Ecklonia maxima extract and mixture of vegetal oils, herbal and seaweed Ascophyllum nodosum extracts increased the nitrate content which, however, remained within the limit set in the EC Regulation No 1258/2011.

Author Contributions: Y.R. and G.C. had the original idea, set up the experimental protocol, coordinated the research and were significantly involved in writing. M.G. and M.C. contributed in nutritional analysis and writing. E.C. and M.M. were responsible for greenhouse tasks. M.C.K. and P.B. contributed in writing and improving the manuscript.

Funding: This research received no external funding.

Acknowledgments: The authors are grateful to Angelo Barbieri for his technical assistance in the greenhouse experiment. The authors also thank Renaud Canaguier, Director of Nixe Laboratory, for his comments on the manuscript.

Conflicts of Interest: The authors declare no conflict of interest. 


\section{References}

1. Duhamel, M.; Vandenkoornhuyse, P. Sustainable agriculture: Possible trajectories from mutualistic symbiosis and plant neodomestication. Trends Plant Sci. 2013, 18, 597-600. [CrossRef] [PubMed]

2. Colla, G.; Hoagland, L.; Ruzzi, M.; Cardarelli, M.; Bonini, P.; Canaguier, R.; Rouphael, Y. Biostimulant action of protein hydrolysates: Unraveling their effects on plant physiology and microbiome. Front. Plant Sci. 2017, 8, 2202. [CrossRef] [PubMed]

3. Rouphael, Y.; Kyriacou, M.C.; Petropoulos, S.A.; De Pascale, S.; Colla, G. Improving vegetable quality in controlled environments. Sci. Hortic. 2018, 234, 275-289. [CrossRef]

4. Rouphael, Y.; Spíchal, L.; Panzarová, K.; Casa, R.; Colla, G. High-throughput plant phenotyping for developing novel biostimulants: From lab to field or from field to lab? Front. Plant Sci. 2018, in press.

5. Amirkhani, M.; Netravali, A.N.; Huang, W.; Taylor, A.G. Investigation of soy protein based biostimulant seed coating for broccoli seedling and plant growth enhancement. HortScience 2016, 51, 1121-1126. [CrossRef]

6. Michalak, I.; Dmytryk, A.; Schroeder, G.; Chojnacka, K. The application of homogenate and filtrate from baltic seaweeds in seedling growth tests. Appl. Sci. 2017, 7, 230. [CrossRef]

7. du Jardin, P. Plant biostimulants: Definition, concept, main categories and regulation. Sci. Hortic. 2015, 196, 3-14. [CrossRef]

8. Colla, G.; Nardi, S.; Cardarelli, M.; Ertani, A.; Lucini, L.; Canaguier, R.; Rouphael, Y. Protein hydrolysates as biostimulants in horticulture. Sci. Hortic. 2015, 196, 28-38. [CrossRef]

9. Colla, G.; Cardarelli, M.; Bonini, P.; Rouphael, Y. Foliar applications of protein hydrolysate, plant and seaweed extracts increase yield but differentially modulate fruit quality of greenhouse tomato. HortScience 2017, 52, 1214-1220. [CrossRef]

10. Battacharyya, D.; Babgohari, M.Z.; Rathor, P.; Prithiviraj, B. Seaweed extracts as biostimulants in horticulture. Sci. Hortic. 2015, 196, 39-48. [CrossRef]

11. Schaafsma, G. Safety of protein hydrolysates, fractions thereof and bioactive peptides in human nutrition. Eur. J. Clin. Nutr. 2009, 63, 1161-1168. [CrossRef] [PubMed]

12. Khan, W.; Rayirath, U.P.; Subramanian, S.; Jithesh, M.N.; Rayorath, P.; Hodges, D.M.; Critchley, A.T.; Craigie, J.S.; Norrie, J.; Prithiviraj, B. Seaweed extracts as biostimulants of plant growth and development. J. Plant Growth Regul. 2009, 28, 386-399. [CrossRef]

13. Craigie, J.S. Seaweed extract stimuli in plant science and agricolture. J. Appl. Phycol. 2011, 23, 371-393. [CrossRef]

14. Botta, A. Enhancing plant tolerance to temperature stress with amino acids: An approach to their mode of action. Acta Hortic. 2013, 1009, 29-35. [CrossRef]

15. Colla, G.; Svecova, E.; Rouphael, Y.; Cardarelli, M.; Reynaud, H.; Canaguier, R.; Rouphael, Y. Effectiveness of a plant-derived protein hydrolysate to improve crop performances under different growing conditions. Acta Hortic. 2013, 1009, 175-179. [CrossRef]

16. Ertani, A.; Schiavon, M.; Muscolo, A.; Nardi, S. Alfalfa plant-derived biostimulant stimulate short-term growth of salt stressed Zea mays L. plants. Plant Soil 2013, 364, 145-158. [CrossRef]

17. Lucini, L.; Rouphael, Y.; Cardarelli, M.; Canaguier, R.; Kumar, P.; Colla, G. The effect of a plant-derived protein hydrolysate on metabolic profiling and crop performance of lettuce grown under saline conditions. Sci. Hortic. 2015, 182, 124-133. [CrossRef]

18. Lucini, L.; Rouphael, Y.; Cardarelli, M.; Bonini, P.; Baffi, C.; Colla, G. A vegetal biopolymer-based biostimulant promoted root growth in melon while triggering brassinosteroids and stress-related compounds. Front. Plant Sci. 2018, 9, 472. [CrossRef] [PubMed]

19. Xu, C.; Leskovar, D. Effects of A. nodosum seaweed extracts on spinach growth, physiology and nutrition valued under drought stress. Sci. Hortic. 2015, 183, 39-47. [CrossRef]

20. Rouphael, Y.; Colla, G.; Giordano, M.; El-Nakhel, C.; Kyriacou, M.C.; De Pascale, S. Foliar applications of a legume-derived protein hydrolysate elicit dose-dependent increases of growth, leaf mineral composition, yield and fruit quality in two greenhouse tomato cultivars. Sci. Hortic. 2017, 226, 353-360. [CrossRef]

21. Rouphael, Y.; De Micco, V.; Arena, C.; Raimondi, G.; Colla, G.; De Pascale, S. Effect of Ecklonia maxima seaweed extract on yield, mineral composition, gas exchange and leaf anatomy of zucchini squash grown under saline conditions. J. Appl. Phycol. 2017, 29, 459-470. [CrossRef] 
22. Rouphael, Y.; Cardarelli, M.; Bonini, P.; Colla, G. Synergistic action of a microbial-based biostimulant and a plant derived-protein hydrolysate enhances lettuce tolerance to alkalinity and salinity. Front. Plant Sci. 2017, 8, 131. [CrossRef] [PubMed]

23. Di Stasio, E.; Rouphael, Y.; Colla, G.; Raimondi, G.; Giordano, M.; Pannico, A.; El-Nakhel, C.; De Pascale, S. The influence of Ecklonia maxima seaweed extract on growth, photosynthetic activity and mineral composition of Brassica rapa L. subsp. sylvestris under nutrient stress conditions. Eur. J. Hortic. Sci. 2017, 82, $286-293$. [CrossRef]

24. Kyriacou, M.C.; Rouphael, Y. Towards a new definition of quality for fresh fruits and vegetables. Sci. Hortic. 2018, 234, 463-469. [CrossRef]

25. Fan, D.; Hodges, D.M.; Zhang, J.; Kirby, C.W.; Ji, X.; Locke, S.J.; Critchley, A.T.; Prithiviraj, B. Commercial extract of brown seaweed Ascophyllum nodosum enhances phenolic antioxidant content of spinach (Spinacia oleracea L.) which protects Caenorhabditis against oxidative and thermal stress. Food Chem. 2011, 124, 195-202. [CrossRef]

26. Ertani, A.; Pizzeghello, D.; Francioso, O.; Sambo, P.; Sanchez-Cortes, S.; Nardi, S. Capsicum chinensis L. growth and nutraceutical properties are enhanced by biostimulants in a long-term period: Chemical and metabolomic approaches. Front. Plant Sci. 2014, 5, 375. [CrossRef] [PubMed]

27. Vig, R.; Dobos, A.; Molnar, K.; Nagy, J. The efficiency of natural foliar fertilizers. Appl. Remote Sens. Geoinform. Environ. Sci. Agric. 2012, 116, 53-64.

28. Colla, G.; Rouphael, Y.; Canaguier, R.; Svecova, E.; Cardarelli, M. Biostimulant action of a plant-derived protein hydrolysate produced through enzymatic hydrolysis. Front. Plant Sci. 2014, 5, 448. [CrossRef] [PubMed]

29. Kopta, T.; Vabkova, J. Effect of selected commercial bio-additives on nutritional value of basil (Ocimumbasilicum L.). Acta Hortic. 2016, 1125, 223-228. [CrossRef]

30. Bremner, J.M. Total nitrogen. In Methods of Soil Analysis; Black, C.A., Evans, D.D., White, D.D., Ensminger, E., Clark, F.E., Eds.; Agronomy Monograph 9, Part 2; American Society of Agronomy, Soil Science Society of America: Madison, WI, USA, 1965; pp. 149-1178.

31. Singleton, V.L.; Orthofer, R.; Lamuela-Raventos, R.M. Analysis of total phenols and other oxidation substrates and antioxidants by means of Folin-Ciocalteu reagent. Methods Enzymol. 1999, 299, 152-178. [CrossRef]

32. Kampfenkel, K.; Van Montagu, M.; Inzé, D. Extraction and determination of ascorbate and dehydroascorbate from plant tissue. Anal. Biochem. 1995, 225, 165-167. [CrossRef] [PubMed]

33. Colla, G.; Rouphael, Y.; Lucini, L.; Canaguier, R.; Stefanoni, W.; Fiorillo, A.; Cardarelli, M. Protein hydrolysate-based biostimulants: Origin, biological activity and application methods. Acta Hortic. 2016, 1148, 27-34. [CrossRef]

34. Ali, N.; Farrell, A.; Ramsubhag, A.; Jayaraman, J. The effect of Ascophyllum nodosum extract on the growth, yield and fruit quality of tomato under tropical conditions. J. Appl. Phycol. 2016, 28, 1353-1362. [CrossRef]

35. Rolland, F.; Moore, B.; Sheen, J. Sugar sensing and signaling in plants. Plant Cell 2002, 14 (Suppl. 1), S185-S205. [CrossRef] [PubMed]

36. Ertani, A.; Francioso, O.; Tinti, A.; Schiavon, M.; Pizzeghello, D.; Nardi, S. Evaluation of seaweed extracts from Laminaria and Ascophyllum nodosum spp. as biostimulants in Zea mays L. using a combination of chemical, biochemical and morphological approaches. Front. Plant Sci. 2018, 9, 428. [CrossRef] [PubMed]

37. Ertani, A.; Schiavon, M.; Nardi, S. Transcriptome-wide identification of differentially expressed genes in Solanum lycopersicon L. in response to an alfalfa-protein hydrolysate using microarrays. Front. Plant Sci. 2017, 8, 1159. [CrossRef] [PubMed]

38. Matsumiya, Y.; Kubo, M. Soybean peptide: Novel plant growth promoting peptide from soybean. In Soybean and Nutrition; El-Shemy, H., Ed.; InTech Europe Publisher: Rijeka, Croatia, 2011; pp. 215-230.

39. Kyriacou, M.C.; Rouphael, Y.; Colla, G.; Zrenner, R.M.; Schwarz, D. Vegetable grafting: The implications of a growing agronomic imperative for vegetable fruit quality and nutritive value. Front. Plant Sci. 2017, 8, 741. [CrossRef] [PubMed]

40. Mancuso, S.; Azzarello, E.; Mugnai, S.; Briand, X. Marine bioactive substances (IPA extract) improve foliar ion uptake and water stress tolerance in potted Vitis vinifera plants. Adv. Hortic. Sci. 2006, 20, 156-161.

41. Fan, D.; Hodges, D.M.; Critchley, A.T.; Prithiviraj, B. A commercial extract of brown macroalga (Ascophyllum nodosum) affects yield and the nutritional quality of Spinach in vitro. Commun. Soil Sci. Plant Anal. 2013, 44, 1873-1884. [CrossRef] 
42. Calvo, P.; Nelson, L.; Kloepper, J.W. Agricultural uses of plant biostimulants. Plant Soil 2014, 383, 3-41. [CrossRef]

43. Gharibzahedi, S.M.T.; Jafari, S.M. The importance of minerals in human nutrition Bioavailability, food fortification, processing effects and nanoencapsulation. Trends Food Sci. Technol. 2017, 62, 119-132. [CrossRef]

44. Levander, O.A. Fruit and vegetable contributions to dietary mineral intake in human health and disease. HortScience 1990, 25, 1486-1488.

45. Colonna, E.; Rouphael, Y.; Barbieri, G.; De Pascale, S. Nutritional quality of leafy vegetables harvested at two light intensities. Food Chem. 2016, 199, 702-710. [CrossRef] [PubMed]

46. Choi, M.; Scholl, U.I.; Yue, P.; Bjorklund, P.; Zhao, B.; Nelson-Williams, C.; Ji, W.; Cho, Y.; Pael, A.; Men, C.J.; et al. $\mathrm{K}^{+}$channel mutations in adrenal aldosterone-producing adenomas and hereditary hypertension. Science 2011, 331, 768-772. [CrossRef] [PubMed]

47. Sestili, F.; Rouphael, Y.; Cardarelli, M.; Pucci, A.; Bonini, P.; Canaguier, R.; Colla, G. Protein hydrolysate stimulates growth and $\mathrm{N}$ uptake in tomato coupled with $\mathrm{N}$-dependent gene expression involved in $\mathrm{N}$ assimilation. Front. Plant Sci. 2018, in press.

48. Colla, G.; Kim, H.J.; Myriacou, M.C.; Rouphael, Y. Nitrate in fruits and vegetables. Sci. Hortic. 2018, 237, 221-238. [CrossRef]

49. Tsouvaltzis, P.; Koukounaras, A.; Siomos, S.A. Application of amino acids improves lettuce crop uniformity and inhibits nitrate accumulation induced by the supplemental inorganic nitrogen fertilization. Int. J. Agric. Biol. 2014, 16, 951-955. [CrossRef]

50. Gil, M.I.; Ferreres, F.; Tomas-Barberan, F.A. Effect of postharvest storage and processing on the antioxidant constituents (flavonoids and vitamin C) of fresh-cut spinach. J. Agric. Food Chem. 1999, 47, 2213-2217. [CrossRef] [PubMed]

51. Kyriacou, M.C.; Rouphael, Y.; Di Gioia, F.; Kyratzis, A.; Serio, F.; Renna, M.; De Pascale, S.; Santamaria, P. Micro-scale vegetable production and the rise of microgreens. Trends Food Sci. Technol. 2016, 57, 103-115. [CrossRef]

52. Kyriacou, M.C.; Soteriou, G.A.; Rouphael, Y.; Siomos, A.S.; Gerasopoulos, D. Configuration of watermelon fruit quality in response to rootstock-mediated harvest maturity and postharvest storage. J. Sci. Food Agric. 2016, 96, 2400-2409. [CrossRef] [PubMed]

53. Rouphael, Y.; Bernardi, J.; Cardarelli, M.; Bernardo, L.; Kane, D.; Colla, G.; Lucini, L. Phenolic compounds and sesquiterpene lactones profile in leaves of nineteen artichoke cultivars. J. Agric. Food Chem. 2016, 64, 8540-8548. [CrossRef] [PubMed] 